\title{
Catalytic methyl mercaptan coupling to ethylene in chabazite: DFT study of the first $\mathrm{C}-\mathrm{C}$ bond formation
}

\author{
J. Baltrusaitis ${ }^{\mathrm{a}, *}$, T. Bučko ${ }^{\mathrm{b}, \mathrm{c}}$, W. Michaels ${ }^{\mathrm{a}}$, M. Makkee $^{\mathrm{d}}$, G. Mul $^{\mathrm{e}}$ \\ a Department of Chemical and Biomolecular Engineering, Lehigh University, B336 Iacocca Hall, 111 Research Drive, Bethlehem, PA 18015, USA \\ ${ }^{\mathrm{b}}$ Department of Physical and Theoretical Chemistry, Faculty of Natural Sciences, Comenius University in Bratislava, Ilkovičova 6, 84215 Bratislava, Slovak \\ Republic \\ c Institute of Inorganic Chemistry, Slovak Academy of Sciences, Dubravska cesta 9, 84536 Bratislava, Slovak Republic, Slovak Republic \\ ${ }^{\mathrm{d}}$ Catalysis Engineering, Chemical Engineering, Delft University of Technology, Julianalaan 136, NL 2628 BL Delft, The Netherlands \\ e Faculty of Science E Technology, University of Twente, PO Box 217, Meander 225, NL 7500 AE, Enschede, The Netherlands
}

\section{A R T I C L E I N F O}

\section{Article history:}

Received 14 September 2015

Received in revised form 6 January 2016

Accepted 10 January 2016

Available online 13 January 2016

\section{Keywords:}

Methyl mercaptan

Chabazite

DFT

Ethylene

\begin{abstract}
A B S T R A C T
Methyl mercaptan, $\mathrm{CH}_{3} \mathrm{SH}$, is an industrial waste as well as the reactive product of several $\mathrm{H}_{2}$ and $\mathrm{H}_{2} \mathrm{~S}$ induced catalytic hydrogenation processes of $\mathrm{COS}$ and $\mathrm{CS}_{2}$. Its coupling into value added products is of great importance in monetizing sour natural gas. In the present work, the full theoretical cycle of catalytic $\mathrm{CH}_{3} \mathrm{SH}$ coupling to form ethene was investigated by means of density functional theory (DFT) using chabazite as a model catalyst with emphasis on the first $\mathrm{C}-\mathrm{C}$ bond formation. Calculated thermodynamics were compared with those of analogous and well established $\mathrm{CH}_{3} \mathrm{OH}$ processes to identify the similarities and differences in the reactive pathways. With few exceptions, $\mathrm{CH}_{3} \mathrm{SH}$ catalytic transformations are of higher free energy when compared to those of $\mathrm{CH}_{3} \mathrm{OH}$. The trimethylsulfonium ion, TMS, isostructural with that of the trimethyloxonium ion, TMO, is shown to be a key reactive intermediate and a thermodynamically stable species leading to ethene formation.
\end{abstract}

(c) 2016 Elsevier B.V. All rights reserved.

\section{Introduction}

Production of value added chemicals and fuels, such as olefins (ethene, propene), benzene derivatives (benzene, toluene, xylene$\mathrm{BTX}$ ), and $\mathrm{C}_{5+}$ liquid fuels is of major industrial importance. When natural gas is used as a raw material, syngas $\left(\mathrm{CO}+\mathrm{H}_{2}\right)$ or methanol $\left(\mathrm{CH}_{3} \mathrm{OH}\right)$ routes are typically used [1-3]. $\mathrm{CH}_{3} \mathrm{OH}$ is a convenient platform molecule $[4,5]$ to obtain higher hydrocarbons since it is liquid in ambient conditions and reacts via well-defined and explored catalytic pathways, thus allowing for a high desired product selectivity [6,7]. Fundamental mechanisms of $\mathrm{CH}_{3} \mathrm{OH}$ catalytic conversion into olefins are important and have been extensively researched due to the industrial and societal impact of the process [8]. Surface related oxonium ylide [9,10], carbene [8,9], dimethyl [8], carbocation [9], and radical [9] routes were considered as mechanistic steps of the first $\mathrm{C}-\mathrm{C}$ bond formation and dimethyl ether (DME) was found to be the main intermediate. Notably, "carbon pool" has been established [11-14] as a currently consensus mech-

\footnotetext{
* Corresponding author.

E-mail address: job314@lehigh.edu (J. Baltrusaitis).
}

anism for olefin production, but it does not account for the first C $-\mathrm{C}$ bond formation.

Far less explored and investigated are the catalytic processes that enable methanethiol or methylmercaptan, $\mathrm{CH}_{3} \mathrm{SH}$, catalytic transformations into value added products. $\mathrm{CH}_{3} \mathrm{SH}$ has attracted significant attention as industrial waste gas in the paper industry, related to the Kraft sulfate pulp process [15]. It also is invariably present in fossil resources, such as natural gas, and needs to be removed to levels below 20 ppmw [16]. Conventional industrial processes for $\mathrm{CH}_{3} \mathrm{SH}$ removal rely on absorption by liquid amines and/or catalytic oxidation releasing highly oxidized sulfur compounds, such as SOx [17]. Very few attempts have been made to catalytically convert $\mathrm{CH}_{3} \mathrm{SH}$ into value added hydrocarbons and oxygenates, including $\mathrm{CH}_{4}[18,19]$, formaldehyde [20,21], BTX [22-24], and olefins [25]. BTX and olefins from $\mathrm{CH}_{3} \mathrm{SH}$ are of particular interest and the concepts of new MTG (Mercaptanto-Gasoline) [26] and MTH (Mercaptan-to-Hydrocarbons) [22] were very recently introduced. This approach can be especially powerful as far as strongly "sour" natural gas containing $\mathrm{CO}_{2}$ and $\mathrm{H}_{2} \mathrm{~S}$ is concerned. The Society of Petroleum Engineers (SPE) estimates that about $40 \%$ of the World's total accessible natural gas reserves are considered sour, totaling to $350 \mathrm{Tcf}$ with over $10 \% \mathrm{H}_{2} \mathrm{~S}$ [27]. The concentrations of acidic gases can range up to $90 \%$ by volume and 


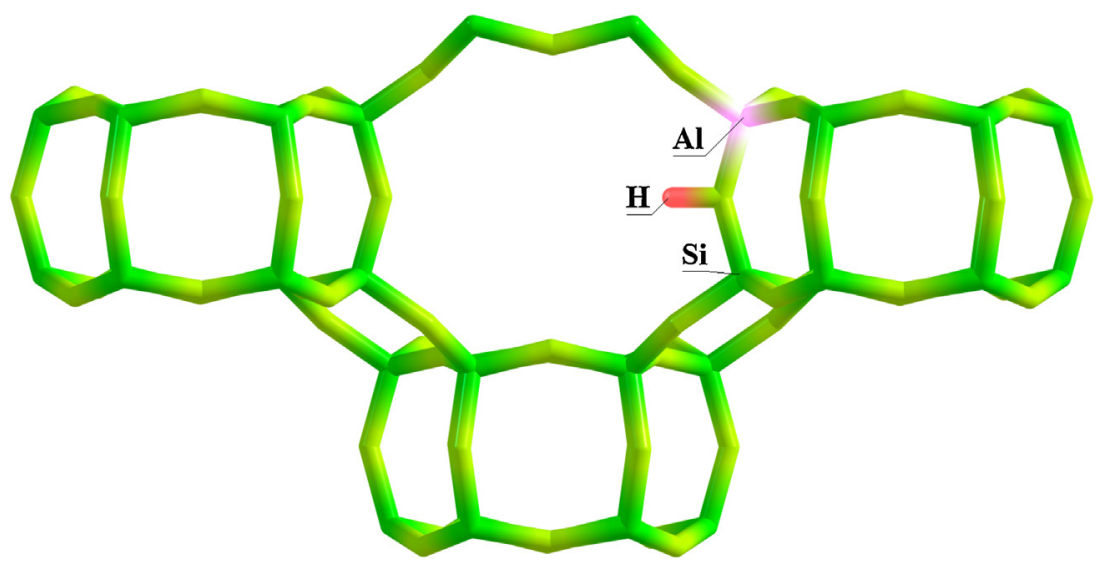

Fig. 1. Representation of the Brønsted acid site in the chabazite framework located at the 01 framework position.

this so-called sub-quality natural gas (SQNG) accounts for approximately $30 \%$ of US natural gas resources [28] with most of the gas wells capped and not utilized [29]. The SPE expects gas demand to grow by as much as $2 \%$ per year over the next two decades, and with the depletion of conventional (sweet) reservoirs, the requirement to develop technologies that would enable the safe and economic exploitation of the sour gas resources is of utmost importance. While sour gas direct processing is difficult due to the corrosivity of $\mathrm{H}_{2} \mathrm{~S}$, catalytic routes have been developed to selectively convert it into $\mathrm{CH}_{3} \mathrm{SH}$. In particular, hydrogen sulfide methane reforming[29] via

$2 \mathrm{H}_{2} \mathrm{~S}+\mathrm{CH}_{4}=4 \mathrm{H}_{2}+\mathrm{CS}_{2}, \Delta H_{298 \mathrm{~K}}=232.4 \mathrm{~kJ} \mathrm{~mol}^{-1}$

has been proposed at temperatures above $1000^{\circ} \mathrm{C}$ with considerable COS amount also formed via

$\mathrm{H}_{2} \mathrm{~S}+\mathrm{CO}=\mathrm{COS}+\mathrm{H}_{2}$.

$\mathrm{CS}_{2}$ and $\mathrm{COS}$ have been shown to selectively react with $\mathrm{H}_{2}$ to form $\mathrm{CH}_{3} \mathrm{SH}$ over $\mathrm{Ni}, \mathrm{K}, \mathrm{Co}$-promoted $\mathrm{MoS}_{2} / \mathrm{SiO}_{2}$ [30-33] providing for indirect routes of sour gas processing to $\mathrm{CH}_{3} \mathrm{SH}$. Other direct pathways of $\mathrm{H}_{2} \mathrm{~S}$ transformation in the presence of $\mathrm{CH}_{4}$ and $\mathrm{CO}_{2}$ have been explored. Baltrusaitis et al. [26] proposed conversion of a $\mathrm{CH}_{4}+\mathrm{H}_{2} \mathrm{~S}$ mixture into $\mathrm{CH}_{3} \mathrm{SH}$ and $\mathrm{H}_{2}$ using light of a low wavelength $(205 \mathrm{~nm})$, potentially overcoming the large barrier for $\mathrm{H}_{3} \mathrm{C}-\mathrm{H}$ bond breaking via conical intersection related relaxation. Syngas in the presence of $\mathrm{H}_{2} \mathrm{~S}$ has been converted to $\mathrm{CH}_{3} \mathrm{SH}$ [34-36], and the same has been achieved using $\mathrm{CO}+\mathrm{H}_{2} \mathrm{~S}$ mixtures $[37,38]$. Finally, Barrault et al. [39] showed selective transformations of both $\mathrm{CO}$ and $\mathrm{CO}_{2}$ in the presence of $\mathrm{H}_{2} \mathrm{~S}$ and $\mathrm{H}_{2}$ to $\mathrm{CH}_{3} \mathrm{SH}$ over $\mathrm{K}$ promoted $\mathrm{WO}_{3} / \mathrm{Al}_{2} \mathrm{O}_{3}$ catalyst. The latter approach can unlock an estimated over $700 \mathrm{Tcf}$ of sour gas reserves that are both $\mathrm{CO}_{2}$ and $\mathrm{H}_{2} \mathrm{~S}$ rich [27]. Thus, potential sour gas processing to yield $\mathrm{CH}_{3} \mathrm{SH}$ as a reactive intermediate has already been explored.

On the other hand, very few attempts of $\mathrm{CH}_{3} \mathrm{SH}$ catalytic coupling have been made to obtain lower olefins or any value added hydrocarbons, such as BTX. Chang and Silvestri [25] reported that at $755 \mathrm{~K}$ using $\mathrm{H}-\mathrm{ZSM}-5$ catalyst, $\mathrm{CH}_{3} \mathrm{SH}$ was converted into $\mathrm{H}_{2} \mathrm{~S}$ (which later can be converted into other high value high volume products, such as $\mathrm{H}_{2} \mathrm{SO}_{4}$ ) and a mixture of hydrocarbons with only $7.0 \%$ selectivity towards $\mathrm{C}_{2}=+\mathrm{C}_{3}=$. Desulfurization was also only partial, with $27.2 \%$ of the carbon feed converted into dimethylsulfide (DMS). Butter et al. [18] claimed high $\mathrm{CH}_{3} \mathrm{SH}$ conversion to $\mathrm{CH}_{4}$ at $531 \mathrm{~K}$ on $\mathrm{H}-\mathrm{ZSM}-5$. Mashkina et al. [19] identified the presence of $\mathrm{CH}_{4}$ when $\mathrm{CH}_{3} \mathrm{SH}$ was processed on various acid catalysts between 623 and $673 \mathrm{~K}$, while at lower temperatures DMS was the only product at equilibrium conversion. A very recent work (2013-2014) by CNRS and TOTAL SA, France, focused on the catalytic conversion of trace amounts of $\mathrm{CH}_{3} \mathrm{SH}$ over acidic zeolites [22-24] and revealed absence of any lower olefins. In particular, selectivity towards (a) $\mathrm{CH}_{4}$, (b) DMS and (c) coke was mainly observed, in addition to the formation of BTX products. This is surprising, since olefins are typically considered to be precursors in BTX formation [40]. It is feasible that, since $\mathrm{CH}_{3} \mathrm{SH}$ catalytic condensation was attempted at temperatures higher than those for $\mathrm{CH}_{3} \mathrm{OH}(823 \mathrm{~K}$ vs $623 \mathrm{~K})$, any ethene formed further reacted on very strong acidic zeolite sites to yield coke and $\mathrm{CH}_{4}$. Finally, Olah et al. [41] used acidic $\mathrm{WO}_{3} / \gamma-\mathrm{Al}_{2} \mathrm{O}_{3}$ catalysts to form $\mathrm{C}_{2} \mathrm{H}_{4}$ from DMS, with the latter being an apparent bottleneck in most of the literature work when attempting to convert $\mathrm{CH}_{3} \mathrm{SH}$.

In this work we performed a comparative DFT calculations of $\mathrm{CH}_{3} \mathrm{OH}$ and $\mathrm{CH}_{3} \mathrm{SH}$ catalytic coupling in chabazite zeolite to form ethene, $\mathrm{CH}_{2}=\mathrm{CH}_{2}$. Since $\mathrm{CH}_{3} \mathrm{OH}$ and $\mathrm{CH}_{3} \mathrm{SH}$ are isostructural, an assumption can be made that their catalytic transformations into ethene should follow the same fundamental mechanisms. This assumption will be verified as one of the research objectives in trying to determine whether there is a common isostructural reactive intermediate for both oxygen and sulfur based species. Thus, we designed this study to directly compare and contrast $\mathrm{CH}_{3} \mathrm{OH}$ and $\mathrm{CH}_{3} \mathrm{SH}$ fundamental reactive steps in order to elucidate the limiting steps of $\mathrm{CH}_{3} \mathrm{SH}$ conversion to lower olefins.

\section{Theoretical methods}

\subsection{Electronic structure calculations}

Periodic DFT calculations have been performed using the VASP code [42-45]. The Kohn-Sham equations have been solved variationally in a plane-wave basis set using the projectoraugmented-wave (PAW) method of Blochl [46], as adapted by Kresse and Joubert [46]. The exchange-correlation energy was described by the PBE generalized gradient approximation [47]. Brillouin-zone sampling was restricted to the $\Gamma$-point. The planewave cutoff was set to $400 \mathrm{eV}$. The convergence criterion for the electronic self-consistency cycle, measured by the change in the total energy between successive iterations, was set to $10^{-6} \mathrm{eV} /$ cell. Local and semi-local density functionals, such as PBE used in this work, fail to describe weak molecular interaction accurately [48]. As a significant part of the interaction energy between alkanes and alkenes and a zeolite is due to van der Waals interactions, semiempirical dispersion corrections to the DFT total energies and forces using Grimme approach (DFT-D2) [49] implemented in the VASP code [50] were used. DFT-D2 combined with PBE functional provides a reasonable accuracy for hydrocarbon-zeolite interactions, 
when compared with high-level methodology (MP2 and RPA) and experiments [51].

\subsection{Structural chabazite model}

Chabazite, a small pore acidic zeolite, has been chosen as a model zeolite as it has been shown experimentally to catalytically convert $\mathrm{CH}_{3} \mathrm{OH}$ to olefins due to the pore selectivity [52,53]. Chabazite is a microporous silicate (zeolite) with a rhombohedral unit cell (space group symmetry $(R \overline{3} m)$ ) consisting of 36 symmetry equivalent tetrahedral sites occupied by silicon atoms coordinated by four asymmetric oxygen atoms. These tetrahedrons are linked via oxygen atoms, forming a double six-membered ring structure. A conventional unit cell obtained from the IZA-SC Database of Zeolite Structures [54] with $\mathrm{a}=13.675 \AA$, b $=13.675 \AA$, $\mathrm{c}=14.767 \AA, \alpha=90^{\circ}$, $\beta=90^{\circ}$ and $\gamma=120^{\circ}$ was converted into a primitive unit cell (containing a $\mathrm{Si}_{12} \mathrm{O}_{24}$ unit) with lattice parameters a,b,c $=9.304 \AA$ and $\alpha, \beta, \gamma=94.60^{\circ}$, similar to $9.319 \AA$ obtained using periodic Hartree Fock models and Gaussian basis sets $[55,56]$. The use of primitive instead of the conventional unit cell allows us to reduce the number of atoms per cell from 108 to 36 . We emphasize that the primitive lattice vectors generate the same Bravais lattice as the lattice vectors of the conventional cell. To create a Brønsted acid site, one of the Si atoms of the framework was replaced by an Al atom and a hydrogen atom was placed onto the 01 oxygen site pointing toward the center of the 8-membered window (see Fig. 1) almost in the plane of the ring [57]. According to experiment [58], this setting represents one out of two highly populated acid sites present in chabazite. Positions of atoms, volume as well as cell parameters were fully optimized using plane-wave cutoff of $520 \mathrm{eV}$ until all forces were less than $0.005 \mathrm{eV} / \AA$. Resulting cell parameters $\mathbf{a}=\mathbf{9 . 3 7 2} \AA \mathrm{A}, \mathbf{b}=\mathbf{9 . 3 6 9} \AA \mathrm{A}, \mathbf{c}=\mathbf{9 . 4 0 7} \AA \mathrm{A}, \boldsymbol{\alpha}=\mathbf{9 4 . 3 1}{ }^{\circ}, \boldsymbol{\beta}=\mathbf{9 4 . 4 4 ^ { \circ }}$ and $\boldsymbol{\gamma} \mathbf{9 3 . 8 9}{ }^{\circ}$ were fixed, while all atomic positions of the zeolitic framework and of the adsorbate molecules were relaxed in simulations presented in this work.

\subsection{Structural optimization calculations and molecular dynamics}

Transition states have been identified using the DIMER method [59], as recently improved by Heyden et al. [60] and using a quasi-Newton method adapted for the saddle-point relaxation, implemented in the program GADGET [61]. Atomic positions were considered to be relaxed if all forces acting on the atoms were smaller than $0.02 \mathrm{eV} / \mathrm{A}$. Transition states were proven to be firstorder saddle points of the potential energy surface using vibrational analysis. The potential energy profiles along intrinsic reaction coordinates $[62,63]$ (IRCs) for the forward and backward reaction steps were identified using the damped velocity Verlet algorithm [64]. The structures corresponding to potential energy minima along the IRC were further relaxed using a conjugate-gradient algorithm such as to satisfy the same optimization criterion as for transition states. Vibrational analysis was performed to ensure that the relaxed structures correspond to true potential energy minima. This procedure guarantees that reactant and product states are linked to transition states via IRCs. The free-energy calculations have been performed using the harmonic/rigid rotor approximation to the transition state theory [65], the Gibbs free energies are reported for $\mathrm{T}=673 \mathrm{~K}$. The use of this level of theory is problematic for entropy-driven reactions, especially if soft degrees of freedom (such as hindered translations or rotations) are involved in the reaction coordinate [66]. The rate-determining steps for mechanisms discussed in this work are, however, enthalpy-driven, hence we expect that this level of theory provides a reasonable description of thermal effects. Born-Oppenheimer molecular dynamics (MD) was performed in the NVT ensemble, temperature was main-

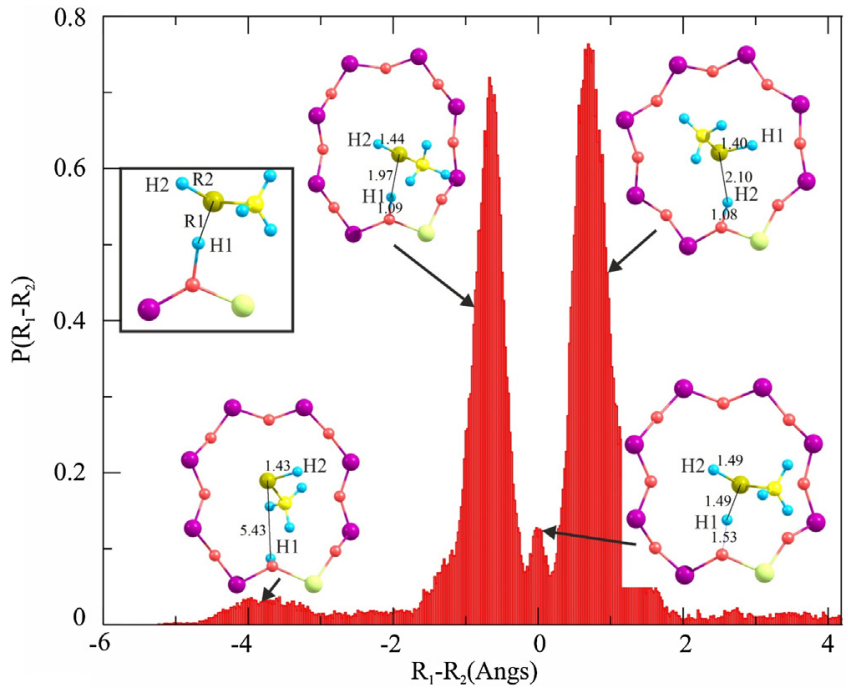

Fig. 2. Probability distribution of the R1-R2 bond length difference of $\mathrm{CH}_{3} \mathrm{SH}$ in chabazite $(\AA)$ determined using molecular dynamics at $600 \mathrm{~K}$. The distances R1 and $\mathrm{R} 2$ are defined in the inset.

tained using the Nosé-Hoover thermostat $[67,68]$. The equations of motion were integrated with a time-step of $1 \mathrm{fs}$.

\section{Results and discussion}

\subsection{Brønsted proton mobility in chabazite and charged} $\mathrm{CH}_{3}\left(\mathrm{SH}_{2}\right)^{+}$species formation

We begin by investigating the interaction of the $-\mathrm{SH}$ moiety in $\mathrm{CH}_{3} \mathrm{SH}$ with the Brønsted acid site formed as described in Section 2.2. The hydrogen atom of $\mathrm{CH}_{3} \mathrm{SH}$ is more prone to dissociate in the presence of a strong Brønsted base than that of $\mathrm{CH}_{3} \mathrm{OH}$, as evidenced by its lower pKa ( 10.3 for $\mathrm{CH}_{3} \mathrm{SH}$ and 15.5 for $\mathrm{CH}_{3} \mathrm{OH}$ ). At the same time, the sulfur atom in $\mathrm{CH}_{3} \mathrm{SH}$ is easily polarizable and acts as a good nucleophile: it could react with the framework Brønsted acid proton to form the charged $\mathrm{CH}_{3}\left(\mathrm{SH}_{2}\right)^{+}$species. At typical reaction temperatures of $600-700 \mathrm{~K}[22,24]$ proton transfer from its probable low-temperature location (a framework oxygen next to aluminum atom) to the other, possibly less basic framework oxygen atom, can be facilitated via thermal diffusion of this charged complex, followed by its dissociation. We performed molecular dynamics (MD) calculations to estimate the probability of $\mathrm{CH}_{3}\left(\mathrm{SH}_{2}\right)^{+}$formation in chabazite. The simulation temperature was set to that reported for $\mathrm{CH}_{3} \mathrm{SH}$ catalytic coupling [22-24] $(600 \mathrm{~K})$, close to expected experimental reaction temperature, and the total length of the MD trajectory was 100 ps. Multiple protonexchange events between the molecule and the acid site have been observed. The probability density was determined for the geometry parameter R1-R2 defined as the difference in distances between the sulfur atom and the hydrogen forming the acid site in the initial configuration (R1), and between the sulfur and hydrogen atoms forming the $\mathrm{SH}$ group in the initial configuration, see Fig. 2. It can be seen that the value of the R1-R2 difference was $\pm(0.2 / 1.5) \AA$ for $\sim 75 \%$ of the simulation time (the change of sign indicates a proton exchange between zeolite and molecule). These configurations correspond to the molecule physisorbed on the acid site. However, formation of a metastable $\mathrm{CH}_{3}\left(\mathrm{SH}_{2}\right)^{+}$complex was also observed with significant likelihood ( $10 \%)$ showing that charge separated species can be formed thus allowing Brønsted protons to become mobile at the reactive temperatures. This will later be shown of critical importance where both Brønsted acid formed on a $\mathrm{Si}-\mathrm{O}-\mathrm{Al}$ junction in the $\mathrm{O} 1$ position, as well as the one formed on the 


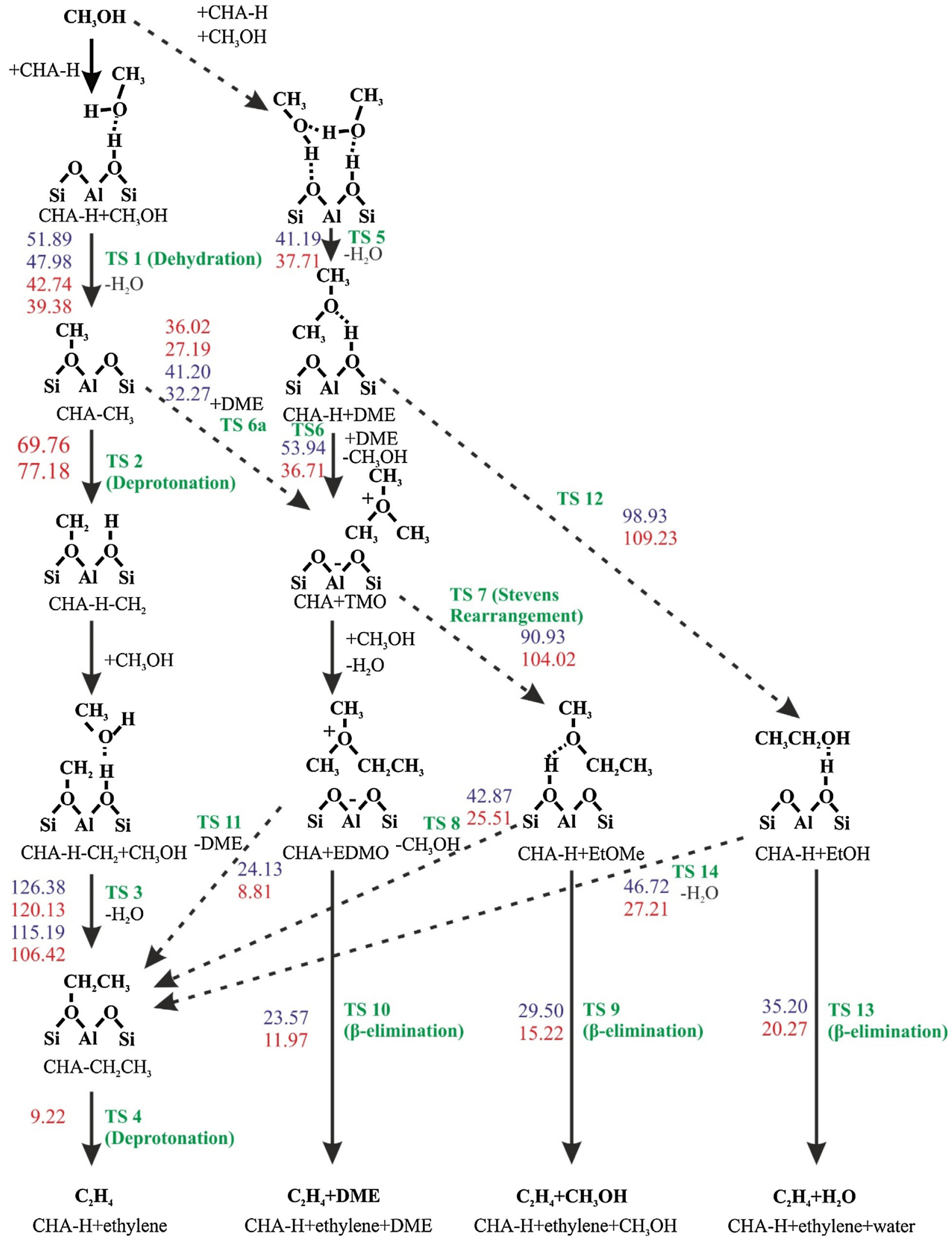

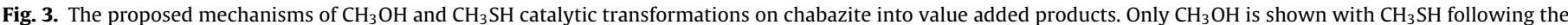

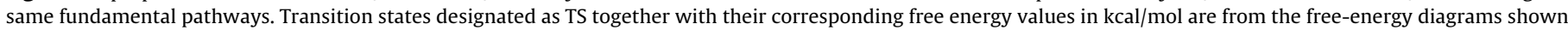

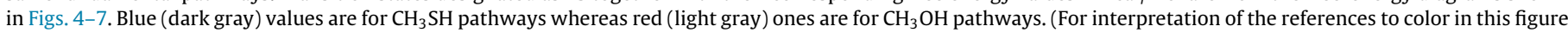
legend, the reader is referred to the web version of this article.) 


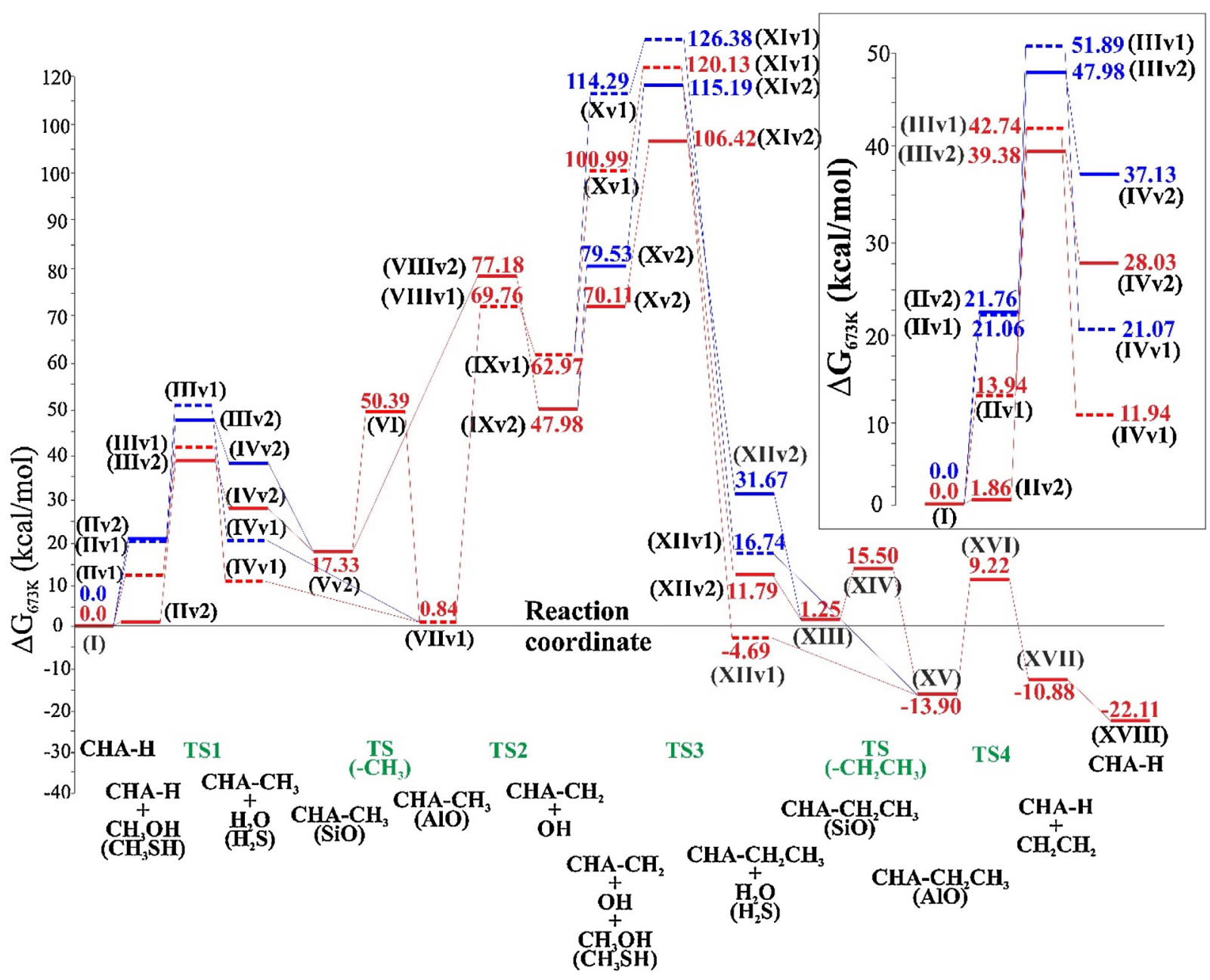

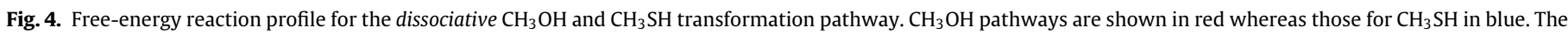

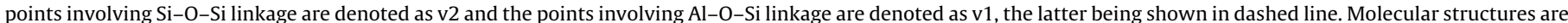

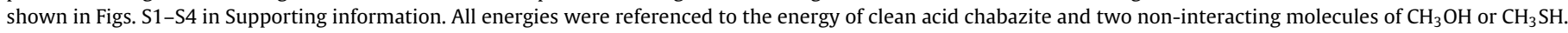

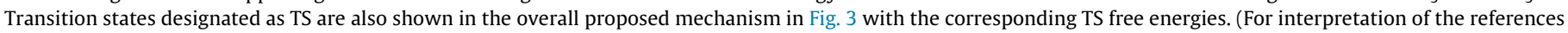
to color in this figure legend, the reader is referred to the web version of this article.)

8-membered ring $\mathrm{Si}-\mathrm{O}-\mathrm{Si}$ junction can be involved mechanistically in $\mathrm{CH}_{3} \mathrm{OH}$ and $\mathrm{CH}_{3} \mathrm{SH}$ catalytic transformations, albeit at rather different energetics. Similar $\mathrm{CH}_{3} \mathrm{OH}$ and $\mathrm{H}_{2} \mathrm{O}$ assisted proton hopping has previously been observed on polyoxometallate Brønsted acids facilitating mobility of surface species, while also allowing for equilibrium locations of protons at an elevated temperature of $433 \mathrm{~K}$ [69]. The barrier for unassisted H-transfer in zeolite is relatively low $(12-25 \mathrm{kcal} / \mathrm{mol})$ [70] compared to the highest free energy barriers on the $\mathrm{C}-\mathrm{C}$ bond formation routes (vide infra) making the exact position of the proton on the framework unimportant for the assessment of the kinetic limitations involved.

\subsection{Formation of the $\mathrm{C}-\mathrm{C}$ bond in $\mathrm{CH}_{3} \mathrm{OH}$ and $\mathrm{CH}_{3} \mathrm{SH}$ on chabazite via a dissociative mechanism}

The proposed mechanistic network shown in Fig. 3 involves $\mathrm{C}-\mathrm{C}$ bond formation via dissociative and associative/oxonium mechanistic steps, commonly proposed to be involved in $\mathrm{CH}_{3} \mathrm{OH}$ coupling reactions [8-10,69,71-73]. The key intermediates involved are surface methoxy $\left(-\mathrm{OCH}_{3}\right)$ and ylide $\left(-\mathrm{CH}_{2}\right)$ in a dissociative mechanism, as well as dimethyl ether (DME), trimethyl oxonium (TMO), ethanol (EtOH), methyl ethyl ether (EtOMe), ethyl dimethyl oxonium ion (EDMO) in associative and oxonium mechanisms. The adsorption of $\mathrm{CH}_{3} \mathrm{OH}\left(\mathrm{CH}_{3} \mathrm{SH}\right)$ on a Brønsted proton to form monomers or dimers at higher concentrations is a commonly accepted initial step in $\mathrm{C}-\mathrm{C}$ bond formation [69,71]. The dissociative mechanism was firstly considered, and the calculated free-energy reaction profile is shown in Fig. 4 with the corresponding optimized structural models shown in Figs. S1-S4 in Supporting information. Minima involving $\mathrm{Si}-\mathrm{O}-\mathrm{Si}$ linkages as a binding site are denoted as v2 and minima involving $\mathrm{Al}-\mathrm{O}-\mathrm{Si}$ linkages are denoted as $\mathrm{v} 1$. The latter is shown with a dashed line. The energies shown in Fig. 4 and discussed in the text are referenced to the energy of clean acid chabazite and two noninteracting molecules of $\mathrm{CH}_{3} \mathrm{OH}$ or $\mathrm{CH}_{3} \mathrm{SH}$. Our calculated Gibbs free-energies of adsorption for $\mathrm{CH}_{3} \mathrm{OH}$ and $\mathrm{CH}_{3} \mathrm{SH}$ are positive with the values of 1.86 and $21.76 \mathrm{kcal} / \mathrm{mol}$, respectively. This is in contrast with zero-temperature values reported in the literature for $\mathrm{CH}_{3} \mathrm{OH}$ in chabazite of -19 to $-13 \mathrm{kcal} / \mathrm{mol}$ calculated using B3LYP and a split valence basis set [74]. The thermal corrections to the Gibbs free energy used in the present work are evidently needed to realistically assess the interaction energies. When a charge separated $\mathrm{CH}_{3}\left(\mathrm{OH}_{2}\right)^{+}$molecule was considered to be formed away from the 01 Brønsted base site (route v1), adsorption free-energies of 13.94 and $21.06 \mathrm{kcal} / \mathrm{mol}$ were obtained for $\mathrm{CH}_{3} \mathrm{OH}$ and $\mathrm{CH}_{3} \mathrm{SH}$, respectively. Notably, both $\mathrm{CHA}-\mathrm{CH}_{3} \mathrm{SH}$ structures (corresponding to routes v1 and v2, see Fig. S3(II v1) and S4(II v2)) were obtained from IRC starting from the corresponding 


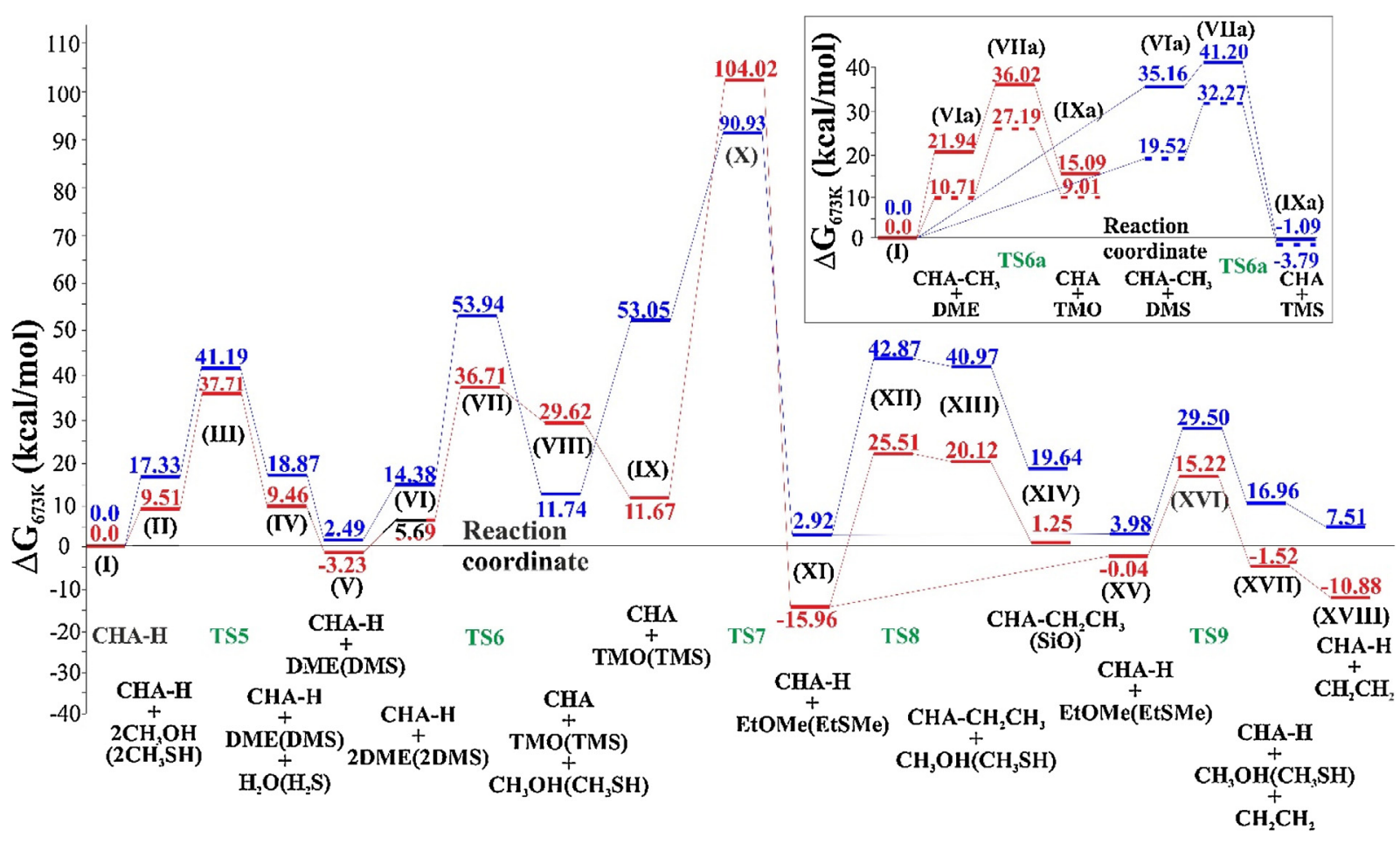

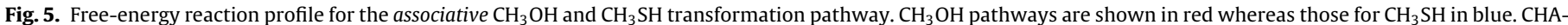

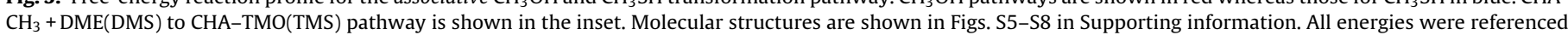

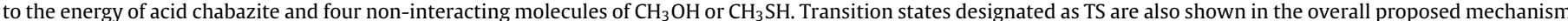

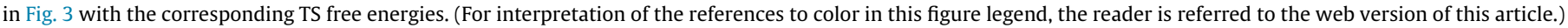

TSs (see Figs. S3(IIIv1) and S4(IIIv2)) and resulted in the charged, almost energy-degenerate complexes. In contrast, $\mathrm{CH}_{3} \mathrm{OH}$ does not necessarily form the metastable intermediate $\mathrm{CH}_{3}\left(\mathrm{OH}_{2}\right)^{+}$complex at the Brønsted site. This reaction step is completed by forming a $\mathrm{H}_{2} \mathrm{O}$ or $\mathrm{H}_{2} \mathrm{~S}$ molecule with the $\mathrm{CH}_{3}$ group attached to the zeolite framework (Figs. S1-S4 (IV)). Relatively high stability of $\mathrm{CHA}-\mathrm{H}+\mathrm{CH}_{3} \mathrm{OH}$ v2 configuration as compared to $\mathrm{CHA}-\mathrm{H}+\mathrm{CH}_{3} \mathrm{OH}$ (IIv1) can be observed from the free energy values. Furthermore, the barrier for $-\mathrm{CH}_{3}$ transfer from $\mathrm{Si}-\mathrm{O}-\mathrm{Si}$ to $\mathrm{Al}-\mathrm{O}-\mathrm{Si}$ (see Fig. S2 (VIv2TS)) is rather large, but equilibrium is shifted towards a methoxy group linked to a more basic $\mathrm{Al}-\mathrm{O}-\mathrm{Si}$ site with the corresponding energy of $0.84 \mathrm{kcal} / \mathrm{mol}$. Methoxy formed on $\mathrm{Al}-\mathrm{O}-\mathrm{Si}$ is very stable thermodynamically and needs to undergo a series of further reactions to become activated. In particular, an apparent rate limiting step for this mechanism is encountered during the TS2 (see Fig. 3) to form ylide incorporated into the CHA structure. As shown in Figs. S1(VII-IX) and S2(V,VIII,IX), this reaction step is linked with a large structural rearrangement of the zeolite framework. Calculated forward reaction barriers of $60-70 \mathrm{kcal} / \mathrm{mol}$ in combination with a rather facile reversion of the ylide into adsorbed methoxy effectively precludes this pathway, in agreement with some literature data reporting a reaction barrier of $78 \mathrm{kcal} / \mathrm{mol}$ in ZSM-5 [71]. Importantly, if the ylide species can be formed via different pathways, such as a radical mechanism [75], it would rapidly convert into the ethoxy $\mathrm{CHA}-\mathrm{CH}_{2} \mathrm{CH}_{3}+\mathrm{H}_{2} \mathrm{O}$ in the presence of a second, sequentially added $\mathrm{CH}_{3} \mathrm{OH}$ molecule (see Figs. $\mathrm{S} 1-\mathrm{S} 4(\mathrm{X}-\mathrm{XII})$ ). This is obvious from the very large ratio between forward and reverse reaction barriers, especially in the case where ylide is formed next to the framework $\mathrm{Al}$ atom (v1). A particularly low energy is needed for the activation of the $\mathrm{CH}_{3}\left(\mathrm{SH}_{2}\right)^{+}$ molecule in the $\mathrm{v} 1$ pathway reacting via TS3 (see Fig. 3 and the corresponding structures in Fig. S3(X-XII)). Consecutively, adsorbed $-\mathrm{CH}_{2} \mathrm{CH}_{3}$ can undergo transfer between $\mathrm{Si}-\mathrm{O}-\mathrm{Si}$ and $\mathrm{Al}-\mathrm{O}-\mathrm{Si}$ linkages after desorbing $\mathrm{H}_{2} \mathrm{O}\left(\mathrm{H}_{2} \mathrm{~S}\right)$ (Fig. $\mathrm{S} 1(\mathrm{XIII}-\mathrm{XV})$ ) with a barrier of only $14.25 \mathrm{kcal} / \mathrm{mol}$, which is much lower than that in the $-\mathrm{CH}_{3}$ case $(33.06 \mathrm{kcal} / \mathrm{mol})$. The ethoxy species formed on the more basic $\mathrm{Al}-\mathrm{O}-\mathrm{Si}$ is thermodynamically more stable by $15.15 \mathrm{kcal} / \mathrm{mol}$ than that linked to the $\mathrm{Si}-\mathrm{O}-\mathrm{Si}$ sequence. The ethoxy species undergoes a deprotonation reaction (Fig. S1(XV-XVII)) via TS4 at relatively low barrier. Desorption of the final reaction product (ethene) is then thermodynamically favored, resulting in the calculated free-energy change of $-22.11 \mathrm{kcal} / \mathrm{mol}$ for the overall process.

\subsection{Formation of the $\mathrm{C}-\mathrm{C}$ bond via associative and oxonium mechanisms}

The associative mechanism is subsequently considered. The calculated free-energy reaction profile is shown in Fig. 5 (energy of clean zeolite and four non-interacting molecules of $\mathrm{CH}_{3} \mathrm{OH}$ or $\mathrm{CH}_{3} \mathrm{SH}$ is used as reference) and the corresponding optimized structural models are presented in Figs. S5-S8 in Supporting information. The initial configuration contains two $\mathrm{CH}_{3} \mathrm{OH}\left(\mathrm{CH}_{3} \mathrm{SH}\right)$ molecules interacting via the $\mathrm{H}$-bonded network of $-\mathrm{OH}(-\mathrm{SH})$ moieties of both molecules and Brønsted acid sites (see Figs. S5(II) and S7(II) in Supporting information). The computed free-energies of adsorption are 9.51 and $17.33 \mathrm{kcal} / \mathrm{mol}$ for $\mathrm{CH}_{3} \mathrm{OH}$ and $\mathrm{CH}_{3} \mathrm{SH}$, respectively, with the latter being less stabilized and thus higher in energy due to the lack of the strong hydrogen bonds in the $\mathrm{S}-\mathrm{H}$ linkages. The reaction of molecules in the adsorption complex over the transition state TS5 (Figs. S5(III) and S7(III)) results in formation of the protonated DME (DMS) species - dimethyloxonium (dimethylsulfonium) (Figs. S5(IV) and S7(IV)) - with forward and reverse barriers being almost identical. This step is followed by the exergonic desorption and deprotonation on Al-O-Si linkages to form DME (DMS) shown in Figs. S5(V) and S7(V). Upon reaction with the second DME (DMS) molecule, a stable CHA$\mathrm{H}+$ DME complex transforms via TS6 (Figs. S5(VII) and S7(VII)) into trimethyl oxonium (TMO) or trimethyl sulfonium (TMS) con- 


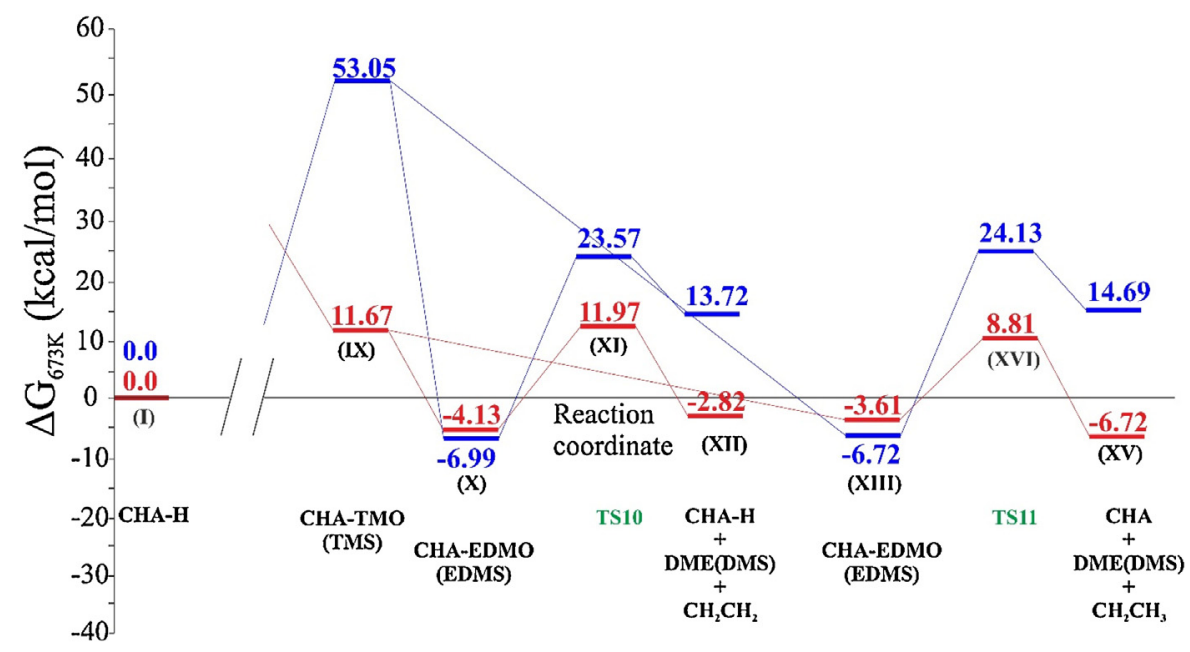

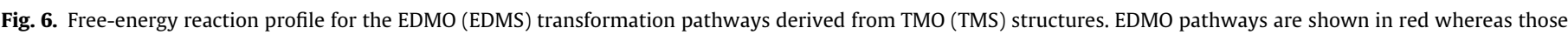

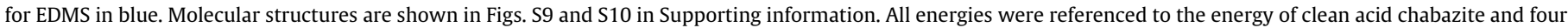

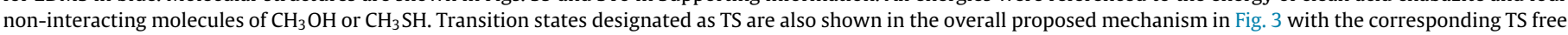
energies. (For interpretation of the references to color in this figure legend, the reader is referred to the web version of this article.)

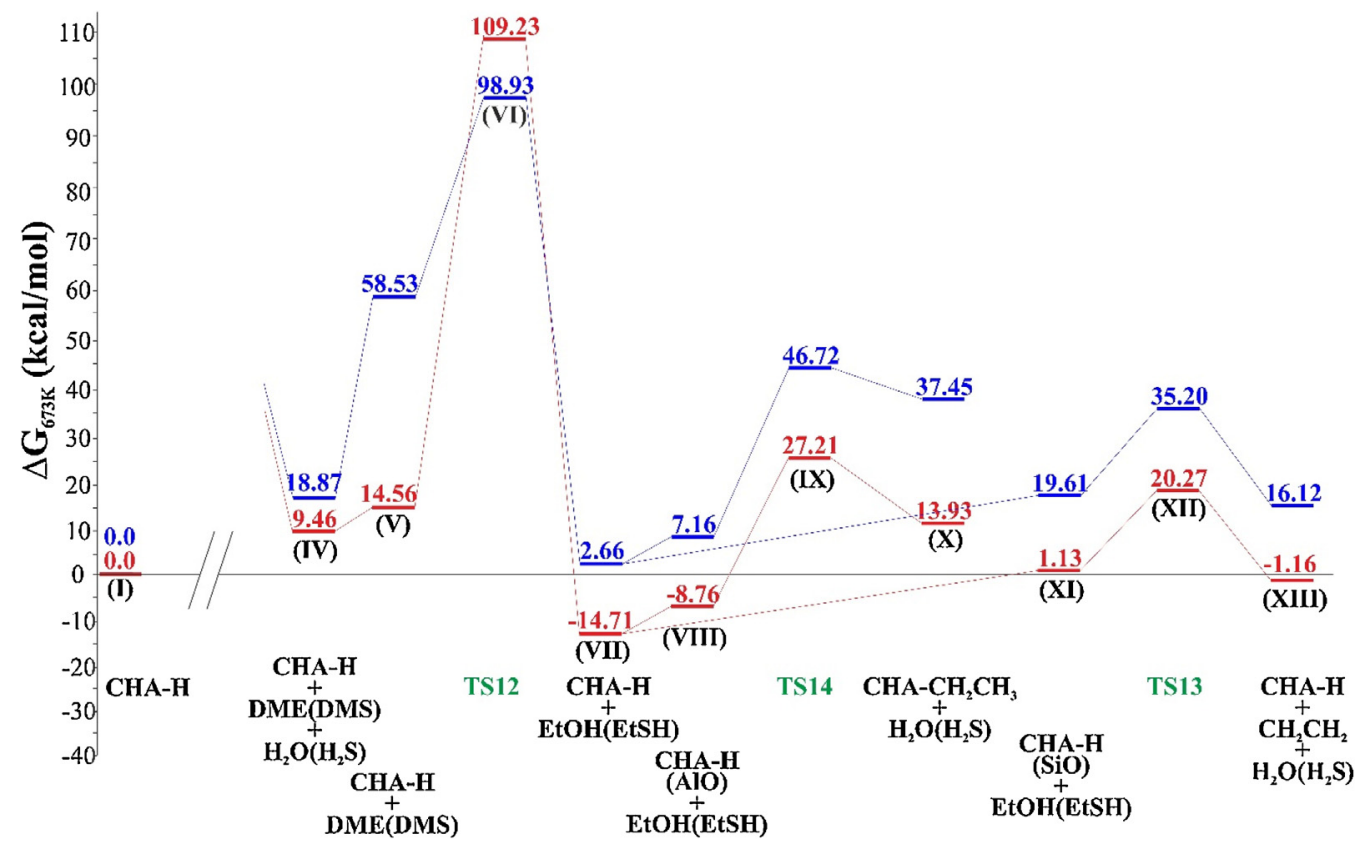

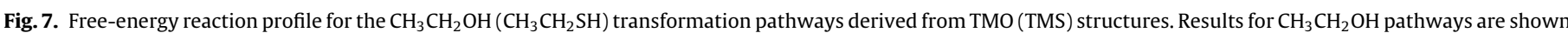

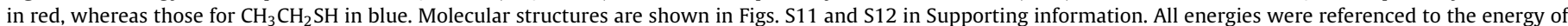

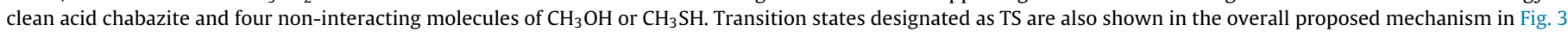
with the corresponding TS free energies. (For interpretation of the references to color in this figure legend, the reader is referred to the web version of this article.)

taining a $\mathrm{CHA}+\mathrm{TMO}+\mathrm{CH}_{3} \mathrm{OH}$ or $\mathrm{CHA}-\mathrm{TMS}+\mathrm{CH}_{3} \mathrm{SH}$ complex (Figs. S5(VIII) and S7(VIII)). The barrier for the reverse process for this part of the reaction in the oxygen pathway is only $7.09 \mathrm{kcal} / \mathrm{mol}$, which is much lower than that for the forward reaction step of $31.02 \mathrm{kcal} / \mathrm{mol}$. TMS formation from two DMS molecules, on the other hand, undergoes a larger activation barrier in the forward direction of $39.56 \mathrm{kcal} / \mathrm{mol}$, but results in a CHA-TMS complex that is much more stable than its oxygenated counterpart. As an alternative route of TMO (TMS) formation, adsorbed methoxy species can undergo relatively facile reaction with DME (DMS) via TS6a, as shown in Fig. 5 inset (the corresponding structures are presented in Figs. S6 and S8 in Supporting information). We considered two variants of this mechanism differing in the initial position of the $\mathrm{CH}_{3}$ group either on $\mathrm{Si}-\mathrm{O}-\mathrm{Si}$ or on $\mathrm{Si}-\mathrm{O}-\mathrm{Al}$ linkages. The reaction proceeded with rather low activation barriers, being most thermodynamically feasible on Al-O-Si linkages. Notably, TMS in configuration IXa is thermodynamically more favorable than TMO. As expected, the methyl group detachment from the $\mathrm{Si}-\mathrm{O}-\mathrm{Si}$ proceeds even faster due to its weaker interaction energy (as compared to the Al-O-Si) with this linkage. This is one of the situations (IXa of TMO vs TMS) where the trend of thermodynamic stability is reversed between oxygen and sulfur species, since oxygen-based compounds appear to be more thermodynamically stable otherwise. The resulting TMO (TMS) species is physisorbed, i.e. very weakly interacting with the CHA framework, and thus the activation barrier to undergo surface facilitated rearrangement to the CHA-H-EtOMe complex via TS7 (Figs. S5(X) and S7(X)) is rather high. Additionally, physisorbed CHA-H + TMS can reconfigure via 
TS7 to form DSMY (dimethyl sulfonium methylide-structure IX in Fig. S7) which, unlike its oxygen counterpart, corresponds to a minimum on PES. This intramolecular rearrangement is highly unfavorable thermodynamically and thus is identified as a rate limiting step for this TMO (TMS) transformation. However, if the intermediate CHA-H-EtOMe is formed, it is rather stable and can undergo decomposition into $\mathrm{CHA}-\mathrm{CH}_{2} \mathrm{CH}_{3}+\mathrm{CH}_{3} \mathrm{OH}$. This unstable intermediate quickly reverts to the initial structure via TS8 (Figs. S5(XII) and S7(XII)), as is obvious from the large free-energy differences between the initial and final reaction states. Alternatively, a concerted mechanism to yield $\mathrm{CHA}-\mathrm{H}+\mathrm{CH}_{2} \mathrm{CH}_{2}+\mathrm{CH}_{3} \mathrm{OH}$ through $\beta$-elimination via TS9 (Figs. S5(XVI) and S7(XVI)) is much more favorable for an oxygen species, as obvious from the comparison of free-energies of activation. The sulfur species, on the other hand, are not stabilized by the CHA framework and revert back into CHA$\mathrm{H}$-EtSMe via low barrier. Most importantly, the relative stability of the products XIV and XVIII suggests that the ethylene formation via the concerted mechanism with EtOMe (EtSMe) as intermediate is thermodynamically more viable.

Fig. 6 shows the free-energy reaction diagram for an alternative pathway for the CHA+TMO transformation (and its sulfur containing analog TMS) proceeding via formation of CHA + EDMO $(\mathrm{CHA}+\mathrm{EDMS})$, rather than undergoing intramolecular rearrangement into EtOMe (EtSMe). In this case, the energy of clean zeolite and four non-interacting molecules of $\mathrm{CH}_{3} \mathrm{OH}$ or $\mathrm{CH}_{3} \mathrm{SH}$ was used to define zero on the $\Delta \mathrm{G}$ axis. The corresponding optimized structural models are shown in Figs. S9 and S10 in Supporting information. The formation of stable EDMO (EDMS) species via alkylation of TMO (TMS) with an additional $\mathrm{CH}_{3} \mathrm{OH}\left(\mathrm{CH}_{3} \mathrm{SH}\right)$ molecule was found to be very exergonic. Here, the alkylation barrier for the sulfur and oxygen containing molecules can be inferred to be similar energetically since the reaction does not involve new $\mathrm{C}-\mathrm{O}$ or $\mathrm{C}-\mathrm{S}$ bond formation, but rather $\mathrm{C}-\mathrm{C}$ bond formation via similar pathways for both oxygen and sulfur compounds. Literature reports that dimethyl oxonium methylide (DOMY) should be an intermediate species in $\mathrm{CHA}+\mathrm{EDMO}$ formation, with the computed $\mathrm{CHA}-\mathrm{H}+\mathrm{DOMY}$ to $\mathrm{CHA}+$ EDMO reaction proceeding via a virtually barrierless process [73]. Our data confirm the absence of the barrier to form CHA + EDMO; CHA-H + DOMY has been located on the potential energy surface as a transient species due to the strong interaction between its $-\mathrm{CH}_{2}$ moiety and framework Si atom (see Fig S9). This step, however, is isostructural between both DOMY and DSMY and would not affect the reactive pathway. The subsequent transformations of CHA + EDMO proceed in two scenarios, one involving a concerted $\mathrm{C}-\mathrm{H}$ bond breaking and Brønsted acid site regeneration on $\mathrm{Al}-\mathrm{O}-\mathrm{Si}$ via TS10, and the other involving an extra step of $-\mathrm{CH}_{2} \mathrm{CH}_{3}$ formation via TS11 followed by deprotonation via the transition state TS4 that was already shown in Fig. $\mathrm{S} 1$ (XVI). In the concerted mechanism for oxygenated species, the reverse barrier is greater than the forward, whereas TS11 leads to a $-\mathrm{CH}_{2} \mathrm{CH}_{3}$ product that is more stable than its EDMO reactant. Hence, for sulfur-containing species, the pathway via TS10 is slightly more favorable as the product $\mathrm{CHA}-\mathrm{H}+\mathrm{DMS}+\mathrm{CH}_{2} \mathrm{CH}_{2}$ is lower in free energy. The situation is reversed in the EDMO case and TS11 mechanism is more favorable thermodynamically. Nevertheless, the overall energetics for both mechanisms is very similar and one should expect that both pathways are active (at different proportions). The ethoxy species can further be deprotonated via mechanism discussed previously in connection with the dissociative mechanism (see Section: 3.2) yielding the gas phase $\mathrm{CH}_{2}=\mathrm{CH}_{2}$ and regenerated Brønsted acid site.

Fig. 7 describes a final mechanism considered with EtOH as an intermediate species [73]. The corresponding optimized structural models are shown in Figs. S11 and S12. A rate limiting step is the intramolecular rearrangement of CHA-H + DME (DMS) (Figs. S11(V) and S12(V)) into CHA-H + EtOH (EtSH) (Figs. S11(VII) and
S12(VII)) with very low reaction rates compared to the mechanisms involving TMO pathways. A notable stability of CHA-H + DME species as opposed to CHA-H+DMS is due to the need in the deprotonation of the latter on the Brønsted site via transient methyl sulfonium methylide (MSMY) shown in Fig. S12 (V) to undergo CHA-H + EtSH formation. If formed, CHA-H + EtOH rearranges into stable $\mathrm{CH}_{2}=\mathrm{CH}_{2}$ via a concerted TS13 mechanism, whereas adsorbed $-\mathrm{CH}_{2} \mathrm{CH}_{3}$ formed via TS14 is much higher in free energy than the initial state, and readily reverts back to CHA-H+EtOH. According to the Gibbs free energies shown in Fig. 7, transformations through TS13 are more likely to lead to stable products than those via TS14. Similar transformations proceed in sulfur pathways, although all of the species are higher in energy than their oxygenated counterparts due to the lack of stabilizing hydrogen bonds with the zeolite framework.

\subsection{Kinetic and thermodynamic aspects of the key intermediates in $\mathrm{CH} 3 \mathrm{SH}$ transformation into ethene}

Data presented so far are consistent with the expectation that TMO is a key intermediate in $\mathrm{CH}_{3} \mathrm{OH}$ transformations to $\mathrm{CH}_{2} \mathrm{CH}_{2}$ [73]. Similarly, reaction of TMS formed via reaction of the adsorbed methoxy with DMS proceeds with a large reverse barrier, as shown in inset of Fig. 5, and serves as a thermodynamic sink for the overall process. The greater thermodynamic stability of the CHA-TMS complex as opposed to that of CHA-TMO in inset of Fig. 5 can be explained by the higher nucleophilicity of sulfur and its lower electronegativity while reverse order in Fig. 6 is due to the fact that on a reactive landscape TMS is effectively reorganized as DSMY (Fig. S7). Combination of these factors allows the formation of a relatively stable charge separated complex of $\mathrm{CHA}^{-}-\mathrm{TMS}^{+}$. $\mathrm{CHA}-\mathrm{H}+\mathrm{DSMY}$ was always formed as a high energy precursor to the further molecular transformation via EDMS intermediate based routes. Moreover, it can be seen from Fig. 6 that DME is an additional product in $\mathrm{CH}_{2} \mathrm{CH}_{2}$ formation, leading to high concentrations in the reactive mixture and further facilitating TMO formation, consistent with the literature $[8,10,25,69]$. DMS is also a thermodynamically favored product of $\mathrm{CH}_{3} \mathrm{SH}$ coupling, in accord with the literature [22-24]. Since higher temperatures need to be maintained to overcome thermodynamic limitations in the equivalent transformations of sulfur products, secondary reaction sequences may proceed, such as $\mathrm{CHA}-\mathrm{H}+\mathrm{TMS}$ to $\mathrm{CHA}+\mathrm{DMS}+\mathrm{CH}_{4}$ or $\mathrm{CHA}+\mathrm{TMS}+\mathrm{CH}_{3} \mathrm{SH}$ to $\mathrm{CHA}-\mathrm{H}+\mathrm{DMS}+\mathrm{CH}_{4}+\mathrm{CH}_{2} \mathrm{~S}$, observed to occur with high rates in the oxygenated counterparts [76]. This is in good agreement with the experimental observation of DMS and $\mathrm{CH}_{4}$ as the main products of the $\mathrm{CH}_{3} \mathrm{SH}$ coupling reaction on zeolites [22-24]. In targeted olefin fuel production, such side reactions forming paraffin products are intuitively undesirable. Mediation of the Brønsted acid strength via metal dopant can be proposed as a possible solution to this problem. The metal-Al-O-Si linkage could possibly prevent the TMS methanation reaction on strong Brønsted acid sites, but the mechanistic data on TMO(TMS) catalytic transformations in zeolites are not readily available. From the data presented, a crucial mechanistic step enabling direct CHA-TMS to CHA-EDMS reaction would proceed via $\mathrm{C}-\mathrm{C}$ bond formation - alkylation with an additional $\mathrm{CH}_{3} \mathrm{SH}$. Efficient $\mathrm{sp}^{3}$ hybridized carbon alkylation reactions via $\mathrm{C}-\mathrm{H}$ bond activation have been recently shown to proceed on $\mathrm{Pd}$ [77], while rather inactive methane $\mathrm{C}-\mathrm{H}$ bonds were activated in Ga/ZSM5 [78].

\section{Conclusions}

$\mathrm{CH}_{3} \mathrm{SH}$ coupling into value added products and the first $\mathrm{C}-\mathrm{C}$ bond formation in ethene was investigated on chabazite Bronsted acidic sites. Thermodynamics was compared with that of 
$\mathrm{CH}_{3} \mathrm{OH}$ to contrast the similarities and differences in the reactive pathways. The trimethylsulfonium ion, TMS, was shown to be a thermodynamically stable species formed in a likely transformation pathway. TMS is isostructural with the trimethyloxonium ion, TMO, but, in contrast to this species, its transformation into ethene via an accompanying EDMS route proceeds via thermodynamically unfavorable CHA-H + DSMY formation. Moderation of the acid site strength in metal doped HZSM5 has recently been shown to increase selectivity towards ethene [7]. Ga and Fe dopants will therefore be explored in future work to elucidate the mechanistic routes related in $\mathrm{CH}_{3} \mathrm{SH}$ catalytic transformations to value added products.

\section{Acknowledgments}

Partial financial support from Lehigh University is gratefully acknowledged. We thank SURFsara (www.surfsara.nl) for the support in using the Cartesius Compute Cluster (the Netherlands). Part of the calculations was performed using computational resources of supercomputing infrastructure of Computing Center of the Slovak Academy of Sciences acquired in projects ITMS 26230120002 and 26210120002 supported by the Research and Development Operational Program funded by the ERDF. T. B. acknowledges support from the project VEGA-1/0338/13. Dr. Steeve Chrétien is gratefully acknowledged for useful discussions.

\section{Appendix A. Supplementary data}

Supplementary data associated with this article can be found, in the online version, at http://dx.doi.org/10.1016/j.apcatb.2016. 01.021 .

\section{References}

[1] J.R. Anderson, Appl. Catal. 47 (1989) 177-196.

[2] J. Baltrusaitis, I. Jansen, J.D. Schuttlefield Christus, Catal. Sci. Technol. 4 (2014) 2397-2411

[3] C. Hammond, S. Conrad, I. Hermans, ChemSusChem 5 (2012) 1668-1686.

[4] G.A. Olah, Angew. Chem. Int. Ed. 44 (2005) 2636-2639.

[5] C.-T. Wu, K.M.K. Yu, F. Liao, N. Young, P. Nellist, A. Dent, A. Kroner, S.C.E. Tsang Nat. Commun. 3 (2012) 1050

[6] C.D. Chang, C.T.-W. Chu, R.F. Socha, J. Catal. 86 (1984) 289-296.

[7] Y. Jin, S. Asaoka, S. Zhang, P. Li, S. Zhao, Fuel Process. Technol. 115 (2013) $34-41$.

[8] G.J. Hutchings, R. Hunter, Catal. Today 6 (1990) 279-306.

[9] M. Stöcker, Microporous Mesoporous Mater. 29 (1999) 3-48.

[10] G.J. Hutchings, G.W. Watson, D.J. Willock, Microporous Mesoporous Mater. 29 (1999) 67-77.

[11] J.F. Haw, W. Song, D.M. Marcus, J.B. Nicholas, Acc. Chem. Res. 36 (2003) 317-326.

[12] I.M. Dahl, S. Kolboe, J. Catal. 149 (1994) 458-464.

[13] M. Bjørgen, S. Svelle, F. Joensen, J. Nerlov, S. Kolboe, F. Bonino, L. Palumbo, S. Bordiga, U. Olsbye, J. Catal. 249 (2007) 195-207.

[14] I. Dahl, S. Kolboe, Catal. Lett. 20 (1993) 329-336.

[15] M.C. Iliuta, F. Larachi, J. Chem. Eng. Data 50 (2005) 1700-1705.

[16] K. Kiu, C. Song, V. Subramani (Eds.), Hydrogen and Syngas Production and Purification Technologies, John Wiley \& Sons, Inc., 2010.

[17] S. Ojala, S. Pitkäaho, T. Laitinen, N. Niskala Koivikko, R. Brahmi, J. Gaálová, L. Matejova, A. Kucherov, S. Päivärinta, C. Hirschmann, T. Nevanperä, M. Riihimäki, M. Pirilä, R. Keiski, Top. Catal. 54 (2011) 1224-1256.

[18] S.A. Butter, A.T. Jurewicz, W.W. Kaeding, Conversion of alcohols, mercaptans, sulfides, halides and/or amines, 1975

[19] A.V. Mashkina, V.R. Grunvald, V.I. Nasteka, B.P. Borodin, V.N. Yakovleva, L.N. Khairulina, React. Kinet. Catal. Lett. 41 (1990) 357-362.

[20] T.L. Burgess, A.G. Gibson, S.J. Furstein, I.E. Wachs, Environ. Prog. 21 (2002) 137-141.

[21] N. Koivikko, T. Laitinen, S. Ojala, S. Pitkäaho, A. Kucherov, R.L. Keiski, Appl. Catal. B Environ. 103 (2011) 72-78.

[22] V. Hulea, E. Huguet, C. Cammarano, A. Lacarriere, R. Durand, C. Leroi, R. Cadours, B. Coq, Appl. Catal. B Environ. 144 (2014) 547-553.

[23] C. Cammarano, E. Huguet, R. Cadours, C. Leroi, B. Coq, V. Hulea, Appl. Catal. B Environ. 156-157 (2014) 128-133.
[24] E. Huguet, B. Coq, R. Durand, C. Leroi, R. Cadours, V. Hulea, Appl. Catal. B Environ. 134-135 (2013) 344-348.

[25] C. Chang, A.J. Silvestri, J. Catal. 47 (1977) 249-259.

[26] J. Baltrusaitis, C. de Graaf, R. Broer, E.V. Patterson, ChemPhysChem 14 (2013) 3960-3970.

[27] F. Lallemand, A. Rocher, N. Aimard, SPE International Oil \& Gas Conference and Exhibition, Beijing, China, SPE, 2006, p. 103802.

[28] R.H. Hugman, E.H. Vidas, P.S. Springer, Energy, Environmental Analysis, Inc., Institute, G.R. Chemical Composition of Discovered and Undiscovered Natural Gas in the Lower-48 United States: Project Summary: Final Report, Gas Research Institute, 1990.

[29] C. Huang, A. T-Raissi, J. Power Sources 163 (2007) 645-652.

[30] O.Y. Gutiérrez, C. Kaufmann, J.A. Lercher, ACS Catal. 1 (2011) 1595-1603.

[31] O.Y. Gutiérrez, L. Zhong, Y. Zhu, J.A. Lercher, ChemCatChem 5 (2013) 3249-3259.

[32] O.Y. Gutiérrez, C. Kaufmann, A. Hrabar, Y. Zhu, J.A. Lercher, J. Catal. 280 (2011) $264-273$.

[33] O.Y. Gutiérrez, C. Kaufmann, J.A. Lercher, ChemCatChem 3 (2011) 1480-1490.

[34] Y. Hao, Y. Zhang, A. Chen, W. Fang, Y. Yang, Catal. Lett. 129 (2009) 486-492.

[35] A. Chen, Q. Wang, Q. Li, Y. Hao, W. Fang, Y. Yang, J. Mol. Catal. A Chem. 283 (2008) 69-76.

[36] A. Chen, Q. Wang, Y. Hao, W. Fang, Y. Yang, Catal. Lett. 121 (2008) 260-265.

[37] C.T. Ratcliffe, P.J. Tromp, Production of methanethiol from H2S and CO. US 4668825, May 1987.

[38] G. Mul, I.E. Wachs, A.S. Hirschon, Catal. Today 78 (2003) 327-337.

[39] J. Barrault, M. Boulinguiez, C. Forquy, R. Maurel, Appl. Catal. 33 (1987) 309-330.

[40] J.H. Lunsford, Catal. Today 63 (2000) 165-174.

[41] G.A. Olah, H. Doggweiler, J.D. Felberg, S. Frohlich, M.J. Grdina, R. Karpeles, T. Keumi, S. Inaba, W.M. Ip, K. Lammertsma, G. Salem, D. Tabor, J. Am. Chem. Soc. 106 (1984) 2143-2149.

[42] G. Kresse, J. Hafner, Phys. Rev. B 49 (1994) 14251-14269.

[43] G. Kresse, J. Furthmüller, Comput. Mater. Sci. 6 (1996) 15-50.

[44] G. Kresse, J. Furthmüller, Phys. Rev. B 54 (1996) 11169-11186.

[45] G. Kresse, J. Hafner, Phys. Rev. B 48 (1993) 13115-13118.

[46] P.E. Blöchl, Phys. Rev. B 50 (1994) 17953-17979.

[47] J.P. Perdew, K. Burke, M. Ernzerhof, Phys. Rev. Lett. 77 (1996) 3865-3868.

[48] L. Benco, T. Demuth, J. Hafner, F. Hutschka, H. Toulhoat, J. Chem. Phys. 114 (2001) 6327-6334

[49] S. Grimme, J. Comput. Chem. 27 (2006) 1787-1799.

[50] T. Bučko, J. Hafner, S. Lebeg̀ue, J.G. Ángyán, J. Phys. Chem. A 114 (2010) 11814-11824.

[51] F. Göltl, A. Grüneis, T. Bučko, J. Hafner, J. Chem. Phys. (2012) 137

[52] G.F. Froment, W.J.H. Dehertog, A. Marchi, J. Catalysis 9 (1992) 1-64.

[53] C.D. Chang, Catal. Rev. 25 (1983) 1-118.

[54] C. Baerlocher, L.B. McCusker, Database of Zeolite Structures: http://www.izastructure.org/databases/.

[55] F. Pascale, P. Ugliengo, B. Civalleri, R. Orlando, P. D’Arco, R. Dovesi, J. Chem Phys. (2002) 117

[56] X. Solans-Monfort, M. Sodupe, V. Branchadell, J. Sauer, R. Orlando, P. Ugliengo, J. Phys. Chem. B 109 (2005) 3539-3545.

[57] B. Civalleri, A.M. Ferrari, M. Llunell, R. Orlando, M. Mérawa, P. Ugliengo, Chem. Mater. 15 (2003) 3996-4004.

[58] L.J. Smith, A. Davidson, A.K. Cheetham, Catal. Lett. 49 (1997) 143-146.

[59] G. Henkelman, H. Jónsson, J. Chem. Phys. 111 (1999) 7010-7022

[60] A. Heyden, A.T. Bell, F.J. Keil, J. Chem. Phys. 123 (2005) 224101/1-224101/14

[61] T. Bučko, J. Hafner, J.G. Ángyán, J. Chem. Phys. 122 (2005) $124508 / 1-124508 / 10$.

[62] K. Fukui, J. Phys. Chem. 74 (1970) 4161-4163

[63] K. Fukui, Acc. Chem. Res. 14 (1981) 363-368.

[64] H.P. Hratchian, H.B. Schlegel, J. Phys. Chem. A 106 (2001) 165-169.

[65] Frank Jensen, Introduction to Computational Chemistry, 2nd ed., John Wiley \& Sons Ltd., 2006.

[66] T. Bučko, L. Benco, J. Hafner, J.G. Ángyán, J. Catal. 279 (2011) 220-228.

[67] W.G. Hoover, Phys. Rev. A 31 (1985) 1695-1697.

[68] S. Nosé, J. Chem. Phys. 81 (1984) 511-519.

[69] R.T. Carr, M. Neurock, E. Iglesia, J. Catal. 278 (2011) 78-93.

[70] M. Sierka, J. Sauer, J. Phys. Chem. B 105 (2001) 1603-1613.

[71] N. Govind, J. Andzelm, K. Rindel, G. Fitzgerald, Int. J. Mol. Sci. 3 (2002) 423-434

[72] D. Lesthaeghe, J. Van der Mynsbrugge, M. Vandichel, M. Waroquier, V. Van Speybroeck, ChemCatChem 3 (2011) 208-212.

[73] D. Lesthaeghe, V. Van Speybroeck, G.B. Marin, M. Waroquier, Chem. Phys. Lett. 417 (2006) 309-315.

[74] V.V. Mihaleva, R.A. van Santen, A.P.J. Jansen, J. Phys. Chem. B 105 (2001) 6874-6879.

[75] S.J. Kim, H.-G. Jang, J.K. Lee, H.-K. Min, S.B. Hong, G. Seo, Chem. Commun. 47 (2011) 9498-9500.

[76] D. Lesthaeghe, V. Van Speybroeck, G.B. Marin, M. Waroquier, Angew. Chem. 118 (2006) 1746-1751

[77] G. Yan, A.J. Borah, L. Wang, M. Yang, Adv. Synth. Catal. 357 (2015) 1333-1350.

[78] V.R. Choudhary, A.K. Kinage, T.V. Choudhary, Science 275 (1997) 1286-1288. 